\title{
Childhood family structure and young adult behaviors
}

\author{
Martha S. Hill ${ }^{1}$, Wei-Jun J. Yeung ${ }^{1}$, Greg J. Duncan ${ }^{2}$ \\ ${ }^{1}$ Institute for Social Research, University of Michigan, P.O. Box 1248 Ann Arbor, \\ MI 48106-1248, USA (FAX: +1-734-647-4575; e-mail: hillm@umich.edu; jeany@umich.edu) \\ ${ }^{2}$ Institute for Policy Research, Northwestern University, 2040 Sheridan Rd., Evanston, \\ IL 60202, USA (FAX: 847-491-9916; e-mail: greg-duncan@nwu.edu)
}

Received: 11 September 1998/Accepted: 27 March 2000

\begin{abstract}
This paper examines a wide variety of forms, and full histories, of family structure to test existing theories of family influences and identify needs for new theories. The focus is on links between childhood family structure and both completed schooling and risk of a nonmarital birth. Using a 27-year span of panel (PSID) data for U.S. children, we find that: (a) change is stressful, (b) timing during childhood is relevant, (c) adults other than parents are important, and (d) two more recently studied family structures (motherwith-grandparent(s) and mother-with-stepfather) do not fit the molds of existing theories. The findings suggest that new theories should consider allocation of resources and reasons people group into family structures.
\end{abstract}

JEL classification: J12, J13, J16

Key words: Demographic economics, marital dissolution, family structure

\section{Introduction}

In recent decades, new forms of family structure have assumed prominence in the lives of U.S. children. Aspects of these changes have been documented repeatedly in cross-sectional studies but less fully explored in a panel context.

All correspondence to Martha S. Hill. The research summarized in this paper was funded by the National Institute for Child Health and Development's Family and Child Well-Being Research Network (U01 HD30947-06), whose generosity is greatly appreciated. We are grateful to Sheldon Danziger, John Ermisch, Marco Francesconi, Christopher Jencks, Saul Hoffman, Gary Solon and two anonymous reviewers for their many helpful suggestions and to Don Hernandez for kindly providing estimates of children's family structures from other sources. Responsible editor: John F. Ermisch. 
Much remains to be learned about what they mean for children. Fortunately, panel studies are now yielding data tracing children and their family life from birth into young adulthood, all during this historical period of greater diversity in family structure. This affords a unique opportunity for a better understanding of how family life operates, the relevance of existing theories of family influences, and new directions for identifying underlying mechanisms.

A particular focus of this paper is the importance of childhood stage to the influence of family structure on children. Taking account of possible variation in effects of family structure by timing of occurrence allows for the possibility that a particular family structure mechanism, be it stress from disruption in family routines, change in the amount or quality of parental supervision, or low levels of economic resources, has stronger effects at some stages of childhood than others because of differences in children's developmental needs or susceptibility to problem behavior. Caring and nurturing, along with nutrition and a good learning environment, are viewed by developmentalists as crucial in early childhood, whereas parental supervision and emotional support may be important in late childhood when risks of behaviors such as dropping out of high school or having a nonmarital birth come into play. Information on the full history of the family structures children encounter while growing up allows us to test the sensitivity of the influence of the family structure to the ages when children encounter it.

The paper also provides a novel perspective on mother-only and non-intact structures by highlighting living arrangements that combine a single mother with grandparent(s) or combine a mother and stepfather. Though still relatively rare, these structures appear to be on the rise. Casper and Bryson (1998), for example, report a $118 \%$ increase between 1970 and 1997 in the number of children living in mother-with-grandparent(s) households. However, time series estimates of the proportion of children in mother-with-grandparent(s) and in mother-with-stepfather families are difficult to locate, and, as far as we can tell, there are no published figures regarding proportions of children ever in such structures, much less what parts of their childhood they spent that way. Research attention is beginning to be directed both to the factors that encourage these living arrangements (e.g., Mauldon and Maestas 1998) and to ways these family structures affect children and adults.

There is clear interest in mother-with-stepfather families because of high divorce and remarriage rates. Interest in mother-with-grandparent(s) families is piqued by the beginnings of a complicated picture of social and economic differences associated with this family structure. Research suggests that grandparent-grandchild coresidence tends to be associated with higher satisfaction on the part of adolescents with their parental relationships, less delinquent activity, but lower grades (Kirby and Uhlenberg 1999).

Observational and ethnographic studies suggest that the added adults in multigenerational families do not necessarily enhance the supervision of youth and can create confusion over who is in charge (Chase-Lansdale et al. 1994; Pattillo-McCoy 1999). Such studies also suggest that children in multigenerational families tend to take on adult roles more quickly because the generations are close in age and this blurs developmental role boundaries to the point that children and parents may behave as siblings (Burton, Obeidallah and Allison, 1996). Analysis of Current Population Survey data indicates that children coresiding with grandparent(s) tend to fare worse economically (Casper and Bryson 1998). All told, however, surprisingly little is known 
about mother-with-grandparent(s) structures. Although our results regarding these noteworthy but rare structures should be viewed cautiously owing to modest sample sizes, they are provocative and call for further research.

Our investigation emphasizes the timing of membership in each family structure in two regards: childhood stage and length of elapsed time. We also examine transitions between structures. Other researchers (e.g., Wu and Martinson 1993; Martinson and Bumpass 1990; and Bumpass and McLanahan 1989), using different data and specifications, have investigated aspects of non-intact or mother-only structures, but they have not specifically examined the mother-with-grandparent(s) structure, nor have they examined the mother-with-stepfather structure at different childhood stages.

Data from the Panel Study of Income Dynamics (PSID) are the basis for our empirical investigation. These data span all years from birth through young adulthood for a representative sample of cohorts born in the late 1960s and early 1970s. With these data, and a focus on family influences on children's educational attainment and daughter's risk of non-marital childbirth, we find some support for existing theories about the ways families influence children. But much of what we find is at odds with these theories.

Our analysis indicates that the stress and economic hardship associated with other-than-two-parent family structures are more important than social control. However, some of our evidence is not well accounted for in any of these theories: (1) parental remarriage and having a stepfather present tend to have beneficial consequences for daughters if these things occurred during adolescence, (2) parental divorce or separation experienced in adolescence tends to have a positive association with sons' education, and (3) the family structure with the greatest detrimental consequences for children, particularly if experienced during adolescence, appears to be one with grandparent(s) present along with a single mother. In addition, variations in consequences by timing of the family structure over the course of childhood do not always fit well with the implications of existing theories.

There is a clear need for further research and for further development of theories about family mechanisms. Our findings suggest that new theories need to take into account the timing of family structure and events, as well as integrate a variety of dimensions, including factors associated with the reasons people group into particular family structures. We leave the task of formulating new theories to future research, but sketch out the terrain they should cover.

The paper begins with a review of existing theories and evidence on the mechanisms by which family structure affects children's characteristics and behaviors. We then focus on our analysis of the PSID data. To set the stage we first examine patterns of childhood family structure experiences. Next we describe the approach and measures used for determining the relevance of existing theories. Estimates for the models are then presented, with discussion highlighting both results that fit and results that do not fit the theories. We end with a discussion of the implications of the findings and further needs for research, with a focus on developing theories and some important aspects to consider when formulating such theories.

\section{Existing theories and relevant literature}

The social science literature posits a number of different causal mechanisms relating family structure to children's outcomes. Our analysis focuses on two 
of the major theories - stress and social control, and takes into account another possible mechanism: family income as emphasized by economic resource theory.

Stress theory posits change in family life as the central cause of family structure effects on children, the idea being that change in family structure prompts reorganization of the roles of family members and adversely affects the nurturing and support provided by parents. (For relevant discussion, see McLoyd et al. 1994; Conger et al. 1993, 1992; Wojtkiewicz 1993; Cherlin et al. 1991; McLanahan 1988; Booth et al. 1984; and Elder 1974). Key aspects of family life for this theory are parental marital events. Family reorganization prompted by parental divorce or (re)marriage is viewed as stressful to parents and children, and the resulting weakening of emotional security and bonds is thought to encourage problem behaviors in children.

Social control theory views adult supervision and monitoring of children's behaviors as important means by which children are kept from engaging in problem behaviors. (For relevant discussion see Brooks-Gunn, forthcoming; Chase-Lansdale et al. 1994; Thornton 1991; McLanahan and Bumpass 1988; Steinberg 1987; Thornton and Camburn 1987; Dornbusch et al. 1985; Hogan and Kitagawa 1985; Hetherington 1979; Cherlin 1978; and Mueller and Pope 1977). Key aspects, according to this theory, are number and types of adults overseeing children. Social control is thought to increase with the number of adults present in the child's home. The more distant the relationship of the adult to the child, though, the weaker the social control. Some types of parents (stepparents) or substitute parents (grandparents) are likely to exert less authority and social control than biological parents because of their more tenuous relationship to the child and because the parenting roles of such relatives are ill-defined (Brooks-Gunn forthcoming; Cherlin 1978). In childhood homes containing both biological parents and grandparents, disagreements between the two regarding parenting style may undermine the social control exerted by both (Chase-Lansdale et al. 1994).

Family income is the operative mechanism in economic hardship theory. (For relevant discussion, see Dodge et al. 1994; Zill and Nord 1994; McLeod and Shanahan 1993; Axinn and Thornton 1992; DaVanzo and Goldscheider 1990; Goldscheider and DaVanzo 1989; Goldscheider and Goldscheider 1987; Weiss 1979; Rubin 1976; and Elder 1974.) Family income is likely to vary with family structure (mother-only families tend to have lower income than two-parent families) and to change with its changes (children's family income tends to drop substantially after parental marital disruption and rise with parental (re)marriage). It can be difficult to distinguish effects of income from other influences of family structure without precise and comprehensive measures of both over the entire course of childhood, and past research has rarely had such measures.

Correlational evidence repeatedly indicates that children fare much worse when raised in non-intact homes (see McLanahan and Sandefur 1994 and Seltzer 1994 for reviews of past research, and, in McLanahan and Sandefur 1994, a comprehensive multi-dataset analysis). Evidence suggests that these correlations are not merely due to lack of control for measured and unmeasured family characteristics (Sandefur and Wells 1997). That children from non-intact homes fare worse could be consistent with social control, stress, and economic hardship theories.

Evidence relating more directly to social control theory indicates that 
children in single-parent families are more susceptible to peer pressure than children in two-parent families (Steinberg 1987; Dornbusch et al. 1985). Lack of social control and more emphasis on peers could result in children having more disciplinary problems and, in adolescence, more intensive dating and sexual involvement. These behaviors, in turn, may encourage young people to leave school early and to form families or unions prematurely, and the effects may be strongest in adolescence. Studies have shown that parental marital disruption leads to early and more frequent sexual activity, premarital pregnancy and births and to the early formation of unions, and some of the evidence suggests that lack of parent supervision is one of the operative mechanisms (see, for example, Thornton 1991; McLanahan and Bumpass 1988; Thornton and Camburn 1987; and Hogan and Kitagawa 1985).

Research regarding stress theory shows that, at least among adolescents, there are linkages between disruptive family events, parents' depression, impaired parenting behavior, and children's impaired school performance, social behavior, and self-esteem (McLoyd et al. 1994; Conger et al. 1992, 1993). Furthermore, $\mathrm{Wu}$ and Martinson (1993) and $\mathrm{Wu}$ (1996) find that it is change in childhood family structure rather than a prolonged period living in a mother-only family that is most strongly linked to young women's chances of having a premarital birth. Wojtkiewicz (1993) also finds that transition into a mother-only family is more important to chances of high school graduation than is duration of time spent in a mother-only family. Some of Wojtkiewicz's findings about other non-intact structures, however, are not entirely consistent with the theory that changes are more important than the length of time spent in a non-intact family.

Few studies of the effects of growing up in single-parent households have had access to sufficiently reliable measures of family income and other familyprocess measures to provide a complete accounting of why children raised in single-parent families do so much worse than children from two-parent families. The handful that have, however, tend to indicate that economic differences account for a sizable portion, but not all, of the adverse effects of being raised in a single-parent household. For example, McLanahan (1985), Hill and Duncan (1987) and McLanahan and Sandefur (1994) all find that parental-income differences account for between one-third and two-thirds of the estimated impact on completed schooling of living in a single-parent family. Other studies find that income differences play a less important role (e.g., Sandefur et al. 1992) or a complex role that varies by type of non-intact family, accounting for single-parent influences but not influences of motherwith-stepfather (Boggess 1998).

The literature indicates differential influences of family structure by sex and age of the child, as well as race (e.g., Boggess 1998). Married parents treat sons and daughters differently, and this may be a factor in the sex differences in effects of changes in family structure (see Seltzer's, 1994, review). Hetherington $(1979,1987)$ found sex differences in reaction to both parents' marital disruption and remarriage. Soon after parental divorce, as well as several years later, sons in families where the divorced mother did not remarry displayed a number of problematic behaviors, including noncompliant behavior. Sons were better adjusted if the custodial mother did remarry; however, daughters were better adjusted if the mother did not remarry. Findings such as these, however, are not entirely consistent with other research (see Seltzer 1994 for a review).

Findings are mixed regarding variation in the influence of family structure 
by child's age (childhood stage). As summarized in Wojtkiewicz (1993), both the amount of time young children spend in the home and their inability to understand and cope with marital disruptions lead us to expect family composition changes occurring early in a child's life to be most harmful, and some research bears this out (Krein 1986; Krein and Beller 1988). However, Wojtkiewicz finds that years spent in mother-only families between the ages of 11 and 15 as opposed to younger ages were associated with substantially reduced chances of graduating from high school. McLanahan and Sandefur (1994) report an insignificant six-percentage-point increase in the risk of dropping out of high school if a marital disruption occurred before age 6 as opposed to after age 12. Haveman and Wolfe (1994) find no significant effect on completed schooling of the timing of years spent living with one parent (although their analysis omits the very early years of childhood).

With such diverse findings in the literature, there is no clear picture of the mechanisms involved and policy implications of the detrimental effects of shifts away from intact families. As some researchers (e.g., Seltzer 1994; Wu and Martinson 1993; and Wojtkiewicz 1993) are beginning to show, our understanding of the underlying processes may be clouded by the failure of empirical measures to reflect the dynamics and many-faceted nature of family structure. Much of the research on childhood family structure has approached the issues as if children experienced the same family structure throughout childhood. Wu (1996) and Wu and Martinson (1993) in their dynamic analysis of young women's premarital births and Wojtkiewicz (1993) in his dynamic analysis of high school graduation help to correct some of these problems. However, this research does not include recent cohorts of young adults and lacks comprehensive control for income.

Wu and Martinson investigate cohorts born 1938-1969 and control for possible cohort differences using only an additive control distinguishing three subgroups - those born $1938-1947$ vs. $1948-1957$ vs. 1958-1969. Wu (1996) and Wojtkiewicz (1993) examine cohorts born 1958-1965. Given the dramatic increase in non-intact families, effects for earlier cohorts may well differ from those for more recent ones. Wu and Martinson and Wojtkiewicz include no measures of childhood family income, and $\mathrm{Wu}$ (1996) includes only measures of family income during adolescence.

The research presented in this paper extends the boundaries of the territory charted by these authors by: (a) examining more recent cohorts of children, (b) measuring family structure with shorter recall, (c) considering structures not yet investigated or little researched (mother-with-grandparent(s) and mother-with-stepfather), and (d) incorporating more comprehensive measures of family income that are well matched to the family structure measures. In extending this work we pay particular attention to: (1) the stage of childhood when a family structure or change in family structure was experienced, (2) presence of adults other than parents (e.g., step-parents or grandparents), (3) parental marital changes as well as associated family structure, (4) family income throughout the course of childhood, and (5) other types of changes that accompany family structure changes (e.g., movement to a different residence, which McLanahan and Sandefur 1994 find important, or changes in mothers' work commitment and consequently in the amount of time spent with their children, which Seltzer, et al. 1989, document as important). We also focus on two types of outcomes for children as young adults - educational attainment and, for daughters, nonmarital childbirth. 


\section{Family structure experiences}

The dramatic growth in mother-only families has fueled much of the research on family structure in recent decades (see, for example, Duncan et al. 1994; Hernandez 1993; Moffitt and Rendall 1993; Duncan and Rodgers 1990; Hofferth 1985; and Bumpass 1984). Yet some of this growth may reflect shifts to family structures that are more complex than a single-parent situation. The presence in single-parent families of adults other than parents rarely has been taken into account, and a family structure consisting of grandparents along with the mother has often been classified as mother-only by researchers.

\subsection{Data}

The Panel Study of Income Dynamics (PSID) data allow us to investigate a wide range of possible family structures and track children's experience of family structures from birth through late childhood. For observing the complete childhood experiences, as well as for the tests of family structure mechanisms reported later in this paper, we rely on 27 years of PSID data. Since 1968 the PSID has followed and annually interviewed a representative sample of about five thousand families. (See Hill 1992 for a full description of the dataset.) Splitoff families are formed when children leave home, when couples divorce, and when more complicated changes break families apart. This procedure produces an unbiased sample of families each year, as well as a continuously representative sample of children born into families. The survey's original design focused on poverty by oversampling lower-income and minority households. Our sample consists of the 1,325 PSID individuals born between 1967 and 1973 and present $^{1}$ in the PSID every wave from birth to age 20. Since this includes individuals from the oversampled households, the data are weighted to adjust for this feature of the sample design as well as differential nonresponse. Barring any nonresponse bias remaining uncorrected by the weighting adjustments we employ, the experiences of this group of children are nationally representative of the cohorts from which they were sampled. ${ }^{2}$

\subsection{Family structure measures}

Our family structure measures are constructed to facilitate investigation of structures that have received relatively little attention in the literature. We distinguish between different types of structures with only one parent, and we separate structures containing a stepparent from other two-parent structures. Our measures are based on demographic information provided in the main data files from the 1968-1991 interviews, plus data from the 1968-1985 Relationship File, which consolidates many years of data to determine all possible pairwise relationships.

Our child-based family structure measures are constructed from the PSID's annual (time-of-interview) categorization of the following family types:

a) "two-parent family": child living with both biological or adoptive parents; ${ }^{3}$

b) "mother-only family": child living with the biological or adoptive mother and no other person older than age 21 other than a sibling; 
c) "mother-with-stepfather family": child living with the biological or adoptive mother and her husband or cohabiting partner who is not himself the biological or adoptive father, ${ }^{4}$

d) "mother-with-grandparent(s) family": child living with the biological or adoptive mother and at least one grandparent but not with the biological, adoptive, or stepfather; other adults may be present in the household; and

e) "other living arrangement": consisting primarily of child living with father only, relatives other than parents or grandparents, or other nonrelatives.

These year-by-year distinctions are used to construct both measures of childhood family status and dynamic formulations of the sequence of family statuses experienced over childhood.

Our most basic status measure is "whether ever in a non-intact family," a crude assessment of childhood family structure frequently used by researchers. A child is classified as being in a non-intact family at some time during childhood if at the time of interview in at least one year from birth to age 15 the child was living in any type of family structure other than a "two-parent family." While this identification procedure misses experiences of non-intact structures in place less than one year and between interviews, it does capture most children's exposure to non-intact family structures.

Because non-intact family types may vary in their influence on children, we provide a finer breakdown by type of non-intact family. Our more detailed set of "whether ever in various family types" measures makes distinctions among the four types of non-intact families listed above, assessing whether a given type of family structure occurred at any time over the entire 15 -year period of childhood.

Our set of measures labeled "whether ever in various family types in each developmental stage" preserves the distinctions among the four types of nonintact families but provides a breakdown by childhood stage. This set of measures assesses incidence within a single developmental stage, distinguishing between three different stages - early childhood (birth to age 5), middle childhood (ages 6-10) and late childhood (ages 11-15).

We also develop a "sequence" measure of family structure based on the basic set of annual assessments of family status. This dynamic measure abandons the distinction of developmental stages and categorizes the entire 15-year period of childhood according to the flow among different types of family status. The categories for the "sequence" measure are:

a) two-parent all 15 years;

b) mother-only all 15 years;

c) mother-only to 2-parent (counting stepparents), continuing until age 15;

d) mother-only to 2-parent and back to mother-only;

e) 2-parent to mother-only, continuing until age 15;

f) 2-parent to mother-only and back to 2-parent, and

g) other sequences, including ones with more than two transitions and ones involving relatives other than the biological father and mother.

These distinctions emphasize transitions between, as opposed to status in, different types of family structures. They capture transitions to and from nonintact families as well as permanent residence in a non-intact family.

Finally, our dynamic measures of family structure also include direct 
measures of potentially disruptive parental marital events. We focus on two types of events - parental divorce or separation and parental marriage or remarriage. These events entail the loss or gain of parent figures, and such events can lead to considerable disorganization and major alterations in family roles. We make distinctions about the timing of these events by specifying the childhood stage - ages $0-5,6-10$, and 11-15 - when the events occurred. Both events could occur in a single childhood stage, and each event could reoccur in different childhood stages. Our specification makes allowance for these possibilities. We also include a variable representing the type of family into which the child was born - whether a two-parent family (as the excluded category), a mother-only family, or some other form of non-intact family. This variable establishes the initial conditions for family structure.

\subsection{Patterns of family structure}

We begin with a comparison of these PSID-based data to independent sources. Weighted descriptive statistics on the PSID's patterns of childhood family structure are presented in Tables 1 and 2. Our own search of the literature and correspondence with prominent scholars in the field provided surprisingly little in the way of independent estimates of these kinds of data. Few sources of published U.S. data include distributions of children across finely detailed categories of family structure. We were unable to locate any source that provided comparable information by single year of age of child or that tracked structures longitudinally for children. All sources with fine delineation of family structure involved cross-sectional estimates with children aggregated into a group aged 1-17. Hence, our reliability checks involved using the PSID to construct simulated cross-sectional estimates applicable to children ages 1-17 in 1980 from the distributions by single year of age and race provided in our Table 1.5

Other sources provide data on the percentage of children not living with both parents, on the percentage living in 'mother-only' homes (an aggregation of our 'mother-only' and 'mother-with-grandparent(s)' categories), and on the percentage living as stepchildren. We were unable to find an independent source of national figures for frequencies of children in mother-withgrandparent(s) arrangements. In addition, we encountered difficulties finding reliable sources for frequencies of children in stepchildren arrangements.

For the percentage of children not living with both parents, we find roughly similar percentages with our simulated cross-sectional estimates compared with estimates from other sources. Our estimate of $16.2 \%$ for nonblacks is comparable to Cherlin's (1988) [CPS-based] estimates of $14.6 \%$ (1975), 17.3\% (1980) and 20.0\% (1985) for whites. Similarly, our estimate of $53.5 \%$ for blacks is roughly comparable to his estimates of $50.6 \%$ (1975), $57.8 \%(1980)$ and $60.5 \%$ (1985) for blacks. There is similar correspondence between our overall estimate of $21.7 \%$ for children as a whole and the Hernandez (1993) [Census and CPS-based] figures of 17.5\% (1970), 23.4\% (1980) and $28.8 \%$ (1988).

Our simulated estimate of the percentage of children in a broad category of 'mother only' family (a category combining our 'mother-only' and 'motherwith-grandparents' types) is somewhat lower than that estimated in Hernandez (1993). We estimate $13.5 \%$ of children to be in this broad category of 


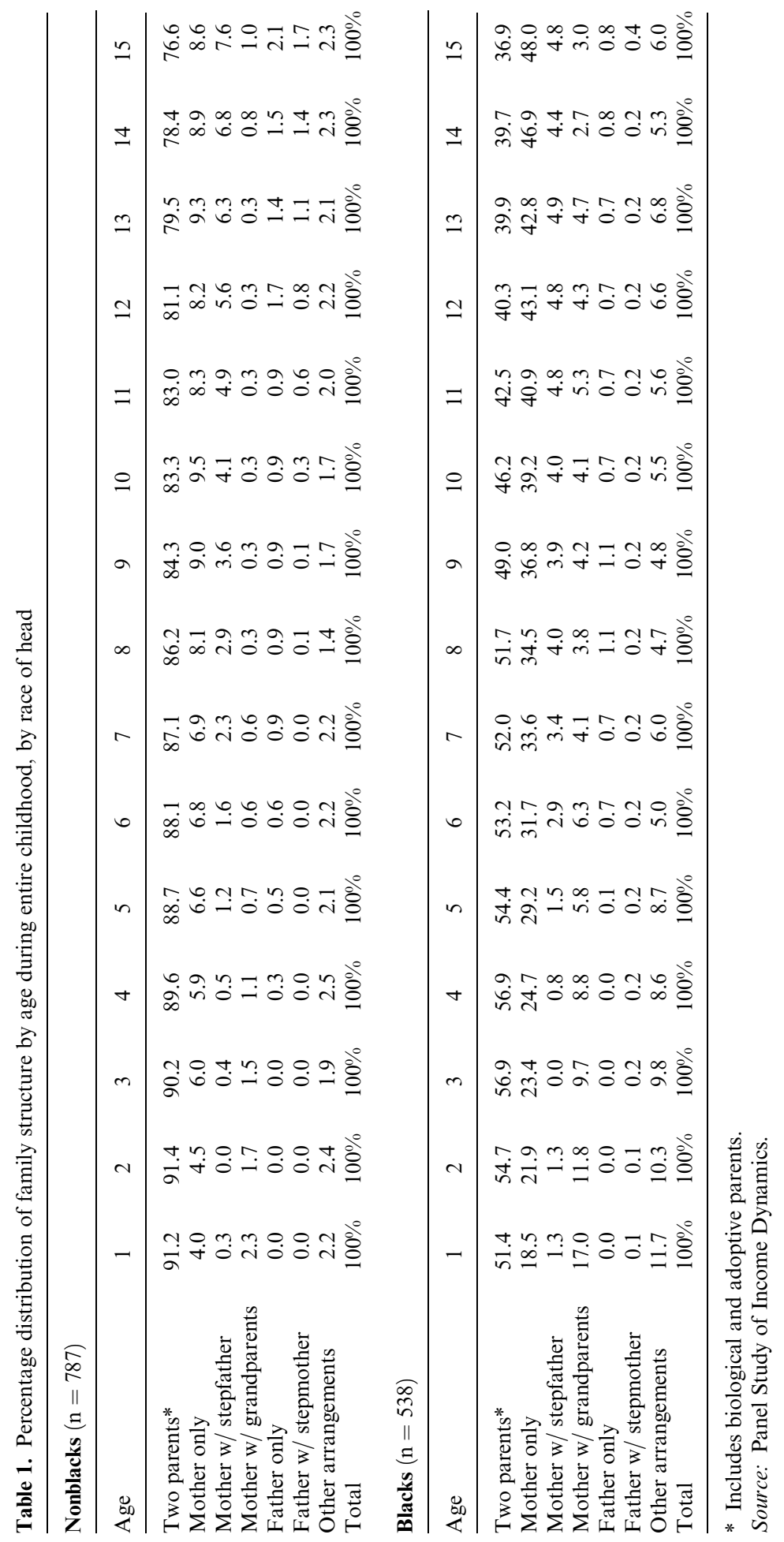


Table 2. Proportion of children with various family structures ages $0-15$, for children born between 1967 and 1973, by race and sex

\begin{tabular}{|c|c|c|c|c|c|c|}
\hline & \multicolumn{3}{|l|}{ Sons } & \multicolumn{3}{|l|}{ Daughters } \\
\hline & $\begin{array}{l}\text { All } \\
(\mathrm{n}=699)\end{array}$ & $\begin{array}{l}\text { Nonblack } \\
(\mathrm{n}=421)\end{array}$ & $\begin{array}{l}\text { Black } \\
(\mathrm{n}=278)\end{array}$ & $\begin{array}{l}\text { All } \\
(\mathrm{n}=626)\end{array}$ & $\begin{array}{l}\text { Nonblack } \\
(\mathrm{n}=366)\end{array}$ & $\begin{array}{l}\text { Black } \\
(\mathrm{n}=260)\end{array}$ \\
\hline & \multicolumn{6}{|c|}{ Whether ever in nonintact family } \\
\hline \multirow[t]{2}{*}{ Yes } & 0.32 & 0.25 & 0.71 & 0.36 & 0.30 & 0.71 \\
\hline & \multicolumn{6}{|c|}{ Whether ever in various family types } \\
\hline Two-parent & 0.90 & 0.95 & 0.62 & 0.89 & 0.93 & 0.65 \\
\hline Mother-only & 0.25 & 0.19 & 0.58 & 0.30 & 0.25 & 0.57 \\
\hline Mother with stepfather & 0.10 & 0.09 & 0.17 & 0.13 & 0.13 & 0.12 \\
\hline Mother with grandparents & 0.07 & 0.04 & 0.21 & 0.05 & 0.03 & 0.16 \\
\hline \multirow[t]{2}{*}{ Other living arrangements } & 0.13 & 0.11 & 0.27 & 0.15 & 0.12 & 0.32 \\
\hline & \multicolumn{6}{|c|}{ Whether ever in various family types in each developmental stage } \\
\hline 2-parent & & & & & & \\
\hline age $0-5$ & 0.89 & 0.94 & 0.58 & 0.89 & 0.93 & 0.64 \\
\hline age $6-10$ & 0.82 & 0.88 & 0.45 & 0.80 & 0.84 & 0.57 \\
\hline age $11-15$ & 0.78 & 0.84 & 0.41 & 0.74 & 0.79 & 0.42 \\
\hline \multicolumn{7}{|l|}{ Mother-only } \\
\hline age $0-5$ & 0.15 & 0.11 & 0.37 & 0.15 & 0.13 & 0.30 \\
\hline age $6-10$ & 0.17 & 0.11 & 0.49 & 0.21 & 0.16 & 0.46 \\
\hline age $11-15$ & 0.17 & 0.12 & 0.52 & 0.21 & 0.15 & 0.54 \\
\hline \multicolumn{7}{|l|}{ Mother w/ stepfa } \\
\hline age $0-10$ & 0.07 & 0.06 & 0.10 & 0.08 & 0.08 & 0.09 \\
\hline age $11-15$ & 0.09 & 0.08 & 0.11 & 0.12 & 0.12 & 0.09 \\
\hline \multicolumn{7}{|l|}{ Mother w/ grandp } \\
\hline age $0-5$ & 0.05 & 0.03 & 0.20 & 0.04 & 0.03 & 0.14 \\
\hline age $6-10$ & 0.02 & 0.01 & 0.10 & 0.01 & 0.00 & 0.06 \\
\hline age $11-15$ & 0.03 & 0.02 & 0.09 & 0.02 & 0.01 & 0.07 \\
\hline \multicolumn{7}{|l|}{ Other } \\
\hline age $0-5$ & 0.05 & 0.04 & 0.16 & 0.08 & 0.06 & 0.19 \\
\hline age $6-10$ & 0.05 & 0.04 & 0.10 & 0.07 & 0.05 & 0.14 \\
\hline \multirow[t]{2}{*}{ age $11-15$} & 0.09 & 0.07 & 0.15 & 0.08 & 0.07 & 0.12 \\
\hline & \multicolumn{6}{|c|}{ Event-based family structure } \\
\hline Born into 2-parent & 0.86 & 0.91 & 0.51 & 0.86 & 0.91 & 0.54 \\
\hline Born into mother-only & 0.11 & 0.07 & 0.38 & 0.10 & 0.06 & 0.33 \\
\hline \multicolumn{6}{|l|}{ Born into other non-two- } & 0.13 \\
\hline \multicolumn{7}{|l|}{ Parental div/sep } \\
\hline age $0-5$ & 0.09 & 0.07 & 0.18 & 0.09 & 0.10 & 0.07 \\
\hline age $6-10$ & 0.07 & 0.07 & 0.11 & 0.10 & 0.10 & 0.10 \\
\hline age $11-15$ & 0.07 & 0.07 & 0.08 & 0.09 & 0.08 & 0.12 \\
\hline \multicolumn{7}{|l|}{ Parental (re)mar } \\
\hline age $0-5$ & 0.05 & 0.05 & 0.06 & 0.06 & 0.07 & 0.04 \\
\hline age $6-10$ & 0.06 & 0.06 & 0.06 & 0.06 & 0.06 & 0.07 \\
\hline \multirow[t]{2}{*}{ age $11-15$} & 0.06 & 0.07 & 0.05 & 0.08 & 0.08 & 0.08 \\
\hline & \multicolumn{6}{|c|}{ Sequence-based family structure } \\
\hline Mother-only all 15 years & 0.03 & 0.01 & 0.13 & 0.03 & 0.01 & 0.14 \\
\hline \multicolumn{7}{|l|}{ Mother-only to 2-parent } \\
\hline$\&$ remained 2-parent & 0.04 & 0.04 & 0.07 & 0.03 & 0.03 & 0.03 \\
\hline \multicolumn{7}{|l|}{ Mother-only to 2-parent } \\
\hline 2-parent all 15 years & 0.71 & 0.78 & 0.31 & 0.66 & 0.73 & 0.31 \\
\hline 2-parent to mother-only & & & & & & \\
\hline \& remained mother-only & 0.07 & 0.05 & 0.19 & 0.10 & 0.08 & 0.19 \\
\hline $\begin{array}{l}\text { 2-parent to mother-only } \\
\text { and back to 2-parent }\end{array}$ & 0.07 & 0.08 & 001 & 009 & 010 & 004 \\
\hline Other sequences & 0.06 & $\begin{array}{l}0.00 \\
0.04\end{array}$ & 0.15 & 0.06 & 0.04 & 0.18 \\
\hline
\end{tabular}


mother-only family compared with Hernandez' estimates of $11.8 \%$ (1970), $16.2 \%(1980)$ and $21.0 \%$ (1988). Here the difference in estimates may in part reflect our categorization of some complex living arrangements with mother but not father present in the 'other arrangements' category, whereas Hernandez may have counted them as 'mother-only.'

Our PSID estimates for stepchildren run low relative to what we could find elsewhere, but the comparison is not entirely direct and confounding elements may distort the comparisons. U.S. Census data from Don Hernandez (correspondence in October 1999) indicate the following percentages of children in a home with mother and stepfather: 6.5\% (1970), 8.4\% (1980) and 10.5\% (1990). This compares with our simulated estimate of $3.7 \%$ of children living as stepchildren. The two types of estimates are not identical; we would expect our figure to be lower since there can be a mixture of biological and stepchildren in the same home. It is exceedingly difficult to gauge how much lower the actual figure might be. If we apply Hernandez' (1993) estimates of percentage of children living in two-parent families to the family structure distributions for children living in two-parent families given in Moorman and Hernandez (1989), we obtain an estimate of the percentage of children who are themselves stepchildren in mother-plus-stepfather homes as follows: 7.0\% (1981) from NHIS data and 8.6\% (1980) from CPS data, compared with our 3.7\%.

Bearing in mind these data quality issues, we turn our attention to what the PSID data tell us about the living arrangements of children. The panel data are treated like pooled cross-sections to provide Table 1's view on family structure by single year of age over childhood. Although crosssectional views can be deceptive about the underlying dynamics, this table does reveal some interesting age patterns. The table is disaggregated by race to show the striking differences for black vs. non-black children in chances of living in non-intact families at every single age during childhood. The age patterns, however, tend to hold for both subgroups.

As children age, the general tendency is for the proportion living in twoparent (non-stepparent) families to fall substantially and the proportion living in mother-only families or in mother-and-stepfather families to rise. Children are most likely to be living in mother-and-grandparent(s) families when they are young: this form of family structure is most common when children are between the ages of one and four. Relative to nonblacks, black children were especially likely to spend some time in a mother-with-grandparent arrangement.

The sizable variation by age in the types of family structure children experience calls into question reliance on static assessments of childhood family structure. A considerable amount of past research has used age 14 as the anchoring point for a childhood family structure measure, but a striking finding in Table 1 is that age 14 is very unrepresentative of family structure experiences in childhood.

The second panel of Table 2 shows in a more summary form the variety in the types of non-intact families children experience. Most children from non-intact families spent some time in a mother-only family, but many spent at least part of their childhood in more complex arrangements. About 10\% experienced life in a mother-with-stepfather family, and roughly half that number were in a mother-with-grandparent(s) family at some time.

A notable fraction of children spent at least part of their childhood in what we categorize as "other living arrangements." This group consists of a diverse 
set of nontraditional family structures containing fathers only or relatives other than parents or grandparents. Each of these component structures tends to have an associated sample size too small for separate analysis. Black children were especially likely to experience these nontraditional structures, with about $30 \%$ in such a family at some point during childhood.

The event-based measures of family structure show that at each childhood stage roughly $10 \%$ of the children experienced a parental divorce or separation and about $5 \%$ experienced parental marriage or remarriage. The sequencebased measures of family structure show that only $3 \%$ of the children spent their entire childhood in a mother-only family, whereas $6 \%$ were born to a mother-only family and later switched either temporarily (especially likely for black children) or permanently to a two-parent family. Of the children in a mother-only family at some point, blacks were much more likely than nonblacks to have that type of structure as their only childhood family structure. About $15 \%$ were born to a two-parent family and later experienced life in a mother-only family either in transition to a new two-parent family or for the remainder of their childhood, and those situations were equally likely.

\section{How well do the theories fit the data?}

Our investigation of the relevance of existing theories focuses on two outcomes for children as young adults - educational attainment and, for females, risk of a first premarital birth. We analyze sons and daughters separately since the child development and sociological literatures frequently find differing influences of family structure by sex of the child. We do not estimate separate models for blacks and non-blacks, owing to the small sample sizes when the sample is divided into race-sex subgroups. Our investigation of possible race interactions yielded few notable instances of them.

Our models assume individual decision-making on the part of the young adult is influenced by exogenous childhood family history. Implicit in this model is the strong assumption that there are no unobserved processes jointly affecting both family background and children's attainments. Yet one hypothesis noted in the economic literature on intergenerational influences is that parents respond to children's mental and physical endowments in their financial support of children's education. To the extent that there is intergenerational correlation in these endowments and children's endowments are unobserved in the data, family income and parents' education may not be exogenous to children's educational attainment (Ermisch and Francesconi 2000, 2001). Sibling models, for example, could identify the influences of family background under weaker assumptions; however, modest sample sizes for sibling pairs in unusual family structures at different childhood stages restrict our ability to estimate sibling models for the wide variation in family structure central to our research. Because of such limitations, we retain our approach of modeling family background as exogenous but are cautious in drawing conclusions about what the results reveal about causal linkages.

\subsection{Outcome measures}

The most recent report of completed schooling, typically that given in the 1995 interview, forms the basis of the years of schooling measure. The age at 


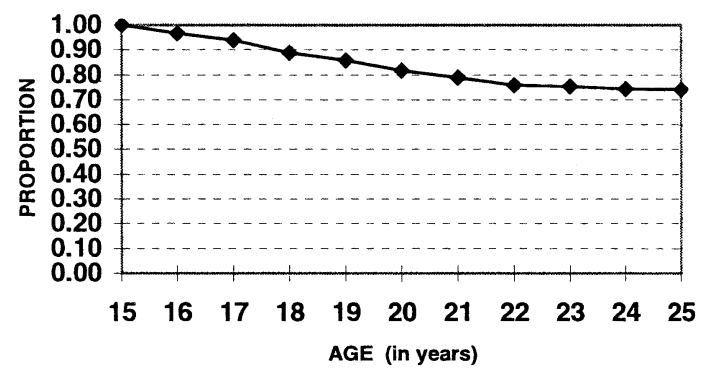

Fig 1. Proportion of daughters with no nonmarital birth by age

which the schooling was reported was between 20 and 25 , depending on the point at which data for the individual became censored. To minimize potential biases from any systematic components in the differential censoring, our regression analyses of educational attainment include a control variable reflecting age at censoring. Educational attainment measured in this way was, on average, about one half year beyond high school, with little difference in mean level for young men versus young women (12.7 years for sons and 12.8 years for daughters, with standard deviations of 1.6 for each).

Risk of a first nonmarital birth is examined only for daughters because of concerns about reliability for a comparable measure for sons. ${ }^{6}$ This focuses on the age at which a first nonmarital birth occurred, if ever, during the observation period. This event-history analysis of nonmarital fertility begins at age 16 and tracks on a monthly basis birth and marital events up through the 1992 interview. Since the majority of sample daughters will never have a nonmarital birth, there is a great deal of right-censorship in these data. In addition, a case could be censored either by attrition from the study or first marriage. The maximum age at the time of right-censorship is age 25 .

Figure 1 traces, by age, the fraction of daughters having no nonmarital birth. It shows that nonmarital first births were most likely to occur to young women between the ages of 18 and 22: about $10 \%$ had a nonmarital first birth by age 18 , compared to about $25 \%$ by age 22 ; relatively few had a nonmarital first birth after age 22 .

\subsection{Models estimated}

In preliminary work we estimated several distinct models of family structure influences. To conserve on space we focus on just two, one that omits family income and one that includes family income. Both control for time-invariant characteristics of the individual and family. The first model facilitates comparisons of findings with prior research having no access to an income measure. The second model helps determine the relevance of the economic hardship theory and provides a base for assessing the relevance of other theories independent of the influence of economic hardship.

All models include time-invariant controls for: (a) race of the head of the family in the year of the child's birth (black $=1$, non-black $=0$ ); (b) mother's education (years of completed schooling); (c) age of the mother at the time of the child's birth, with missing data set to zero; (d) a dichotomous indicator of 
whether there is non-missing data on the mother's age at the time of the child's birth (yes $=1$, no $=0$ ); (e) total number of the child's siblings; (f) residence in the South (ever yes $=1$, never $=0)$; $(\mathrm{g})$ the average unemployment rate in the child's county of residence between ages 11 and 15; and (h) the average AFDC benefit in the child's state of residence at age 14, expressed in thousands of 1993 dollars. Means and standard deviations for these variables are provided in the Appendix Table 1.

Two distinct measures of childhood family income are used in our estimation process. When a measure of the family structure itself is the focus, family income is measured as average annual income (inflation-adjusted to units of 10,0001993 dollars). ${ }^{7}$ When parental marital events are the focus, family income is measured in terms of change, specifying whether or not there was a drop in family income of $50 \%$ or more during the specified period. ${ }^{8}$ Family income is adjusted for family size with the inclusion of controls for family structure (which assesses presence of adults) and number of siblings.

\subsection{How results compare to findings in the literature}

Comparisons with prior research findings are complicated by differences in specification. These differences include: sample construction (other researchers have often combined sons and daughters, disaggregated by race, or both); disaggregation of family structure by types (e.g., other researchers have classified mother-with-grandparent(s) as part of mother-only); specification of the outcome (e.g., other researchers sometimes use high school completion rather than years of education as their education outcome); and choice of control variables (e.g., other researchers have tended to omit factors such as childhood family income, area-based measures, or age of mother at the birth of the child).

For tightest comparability to prior research, we look to findings with family structure designated in terms of the dichotomy of 'whether ever in a non-intact family' during childhood and with childhood family income omitted from the regressions (see first panel of estimates in Table 3). Coefficients are in the directions expected from comparable prior research, showing time spent in a non-intact family to be associated with lower levels of educational attainment and a higher risk of non-marital birth. ${ }^{9}$

Disaggregating non-intact family by type (second panel in Table 3 ) reveals similarities as well with earlier findings in terms of the direction of associations for more specific types of non-intact families. In our findings for both motheronly and mother-with-grandparent(s) structures we see negative associations with educational attainment and positive associations with risk of a nonmarital birth. Wojtkiewicz's (1993) and Wu and Martinson's (1993) findings using an aggregated form of mother-only structure that include the motherwith-grandparent(s) type yielded coefficients in the same directions. ${ }^{10}$ Results for mother-with-stepfather structures also bear similarities to prior research: like Wojtkiewicz (1993) we find no evidence of a relationship to educational attainment, and like Wu and Martinson's (1993) results for blacks, though not for whites, we find no evidence of a relationship to risk of a non-intact birth. ${ }^{11}$

Regarding structures rarely viewed in the literature, we find weak evidence for the importance of mother-and-grandparent(s) structure, at least with regard to children's education. This type of non-intact structure displays large 
Table 3. Relationship of whole-childhood measures of family structure to children's completed schooling and risk of having a first nonmarital birth, by sex

\begin{tabular}{|c|c|c|c|c|}
\hline & \multicolumn{2}{|c|}{$\begin{array}{l}\text { Years of completed } \\
\text { schooling }\end{array}$} & \multicolumn{2}{|c|}{ Nonmarital birth } \\
\hline & $\begin{array}{l}\text { Sons } \\
\text { coeff. } \\
\text { (std.err.) }\end{array}$ & $\begin{array}{l}\text { Daughters } \\
\text { coeff } \\
\text { (std.err.) }\end{array}$ & $\begin{array}{l}\text { Daughters } \\
\text { coeff } \\
\text { (std.err) }\end{array}$ & Risk \\
\hline Whether ever in non-intact family & $\begin{array}{r}-0.23^{+} \\
(0.13)\end{array}$ & $\begin{array}{c}-0.27 * * \\
(0.12)\end{array}$ & $\begin{array}{l}0.53^{* * *} \\
(0.11)\end{array}$ & 1.70 \\
\hline Adjusted R-squared/log likelihood & 0.175 & 0.275 & -646.4 & \\
\hline \multicolumn{5}{|l|}{ Whether ever in various family types } \\
\hline Mother-only & $\begin{array}{c}-0.25 \\
(0.16)\end{array}$ & $\begin{array}{c}0.01 \\
(0.15)\end{array}$ & $\begin{array}{c}0.45 \\
(0.24)\end{array}$ & 1.57 \\
\hline Mother with grandparent(s) & $\begin{array}{c}-0.34 \\
(0.23)\end{array}$ & $\begin{array}{r}-0.49^{+} \\
(0.26)\end{array}$ & $\begin{array}{l}0.17^{+} \\
(0.33)\end{array}$ & 1.19 \\
\hline Mother with stepfather & $\begin{array}{c}0.15 \\
(0.21)\end{array}$ & $\begin{array}{c}-0.03 \\
(0.19)\end{array}$ & $\begin{array}{c}0.02 \\
(0.28)\end{array}$ & 1.02 \\
\hline Other living arrangements & $\begin{array}{c}-0.28 \\
(0.18)\end{array}$ & $\begin{array}{r}-0.36^{*} \\
(0.17)\end{array}$ & $\begin{array}{l}0.81^{* * *} \\
(0.24)\end{array}$ & 2.25 \\
\hline Adjusted $R$-squared/log likelihood & 0.181 & 0.279 & -647.2 & \\
\hline \multicolumn{5}{|l|}{$\begin{array}{l}\text { Sequence-based family structure } \\
\text { 2-parent all } 15 \text { years (omitted) }\end{array}$} \\
\hline Mother-only all 15 years & $\begin{array}{r}-0.72^{*} \\
(0.36)\end{array}$ & $\begin{array}{c}-0.01 \\
(0.36)\end{array}$ & $\begin{array}{c}-0.60 \\
(0.45)\end{array}$ & 0.55 \\
\hline Mother-only to 2-parent & $\begin{array}{c}-0.08 \\
(0.28)\end{array}$ & $\begin{array}{c}-0.28 \\
(0.33)\end{array}$ & $\begin{array}{c}0.30 \\
(0.62)\end{array}$ & 1.35 \\
\hline Mother-only to 2-parent to Mother-only & $\begin{array}{c}-1.36^{* *} \\
(0.37)\end{array}$ & $\begin{array}{c}-0.47 \\
(0.30)\end{array}$ & $\begin{array}{l}1.48^{* * *} \\
(0.38)\end{array}$ & 4.39 \\
\hline 2-Parent to Mother-only & $\begin{array}{c}0.04 \\
(0.22)\end{array}$ & $\begin{array}{r}-0.28 \\
(0.19)\end{array}$ & $\begin{array}{l}0.98^{* *} \\
(0.31)\end{array}$ & 2.66 \\
\hline 2-Parent to Mother-only to 2-parent & $\begin{array}{c}0.03 \\
(0.23)\end{array}$ & $\begin{array}{c}-0.02 \\
(0.19)\end{array}$ & $\begin{array}{l}0.98^{* *} \\
(0.32)\end{array}$ & 2.66 \\
\hline Other sequences & $\begin{array}{l}-0.78^{* *} \\
(0.24)\end{array}$ & $\begin{array}{c}-0.32 \\
(0.24)\end{array}$ & $\begin{array}{l}0.98^{* *} \\
(0.32)\end{array}$ & 2.66 \\
\hline Adjusted $R$-squared/log likelihood & 0.194 & 0.270 & -646.7 & \\
\hline
\end{tabular}

negative, though insignificant, coefficients in the education equations of both sons and daughters.

Switching to sequences of family structure (bottom panel in Table 3) we see evidence of the mother-only structure throughout childhood being less important than some changes in family structure. The stable mother-only structure registers a statistically significant difference from the stable two-parent structure only in the sons' educational attainment regression. A transition structure - mother-only to two-parent back to mother-only - stands out with a stronger link to children's outcomes. Sons experiencing this structure have considerably 
lower educational attainment than sons from two-parent or mother-only structures. Daughters from this transition structure have a higher risk of a nonmarital birth than daughters from stable two-parent or mother-only structures. Indeed, daughters from most any transition structure run a higher risk of a nonmarital birth than daughters from the stable structures. Yet family structure sequences matter little for daughters' educational attainment, with transition structures showing negative but insignificant coefficients and the stable motheronly structure having an essentially zero coefficient. The tenor of these findings is roughly consistent with that of Wojtkiewicz (1993) and Wu and Martinson (1993). Given the differentials we find for sons' and daughters' educational attainment, collectively our results are in line with Wojtkiewicz's major conclusions regarding children's odds of finishing high school: a negative association with change in family structure and no association with prolonged stay in a mother-only family. Our results showing the heightened linkage of daughters' risk of a non-marital birth to transition structures fit with $\mathrm{Wu}$ and Martinson's finding that, for both white and black daughters, risk of a non-marital birth increases with number of changes in family structure.

Overall, our results tend to show similar but weaker associations than those of earlier researchers, with many of our coefficients failing to achieve significance at conventional levels. It is possible that these differences in findings are attributable to cohort differences since the other researchers investigated earlier cohorts of children, who were less likely to experience a mother-only structure and hence may have experienced greater differences in family life. The influence of non-intact family structures may well have diminished as they have become more common, but tests of such an assertion await further research.

\subsection{Timing during childhood}

One of the unique contributions of this paper is being able to observe variation in the influence of family structure over the course of childhood. To assess the role of timing of family structure influences, we turn to stage-specific measures constructed separately for early childhood (ages $0-5$ ), middle childhood (ages 6-10) and late childhood (ages 11-15). Tables 4 and 5 present regression results regarding these stage-specific measures. Table 4 focuses on the type of family structure experienced at each stage of childhood. Table 5 focuses on change in family structure, with the change assessed in terms of parental marital events at different stages of childhood (controlling for the family structure children are born into).

These tables, each with precise timing of family structure experiences, emphasize the importance of: (1) timing, (2) new types of family structure, and (3) change as opposed to extended stay in non-intact families. Predictive power improves when we switch from regressions using 'whether ever in a non-intact family' as the sole indicator of childhood family structure to specifications differentiated by childhood stage and type of non-intact family (not shown). ${ }^{12}$ The enhanced predictive power appears to be concentrated in distinguishing two family structures, mother-with-stepfather and motherwith-grandparent(s), at particular childhood stages (see Table 4).

There is suggestive evidence that the mother-with-stepfather arrangement has some importance for daughters' subsequent educational attainment with the direction of the association differing by childhood stage. Daughters in 
Table 4. Relationship of family structure at different childhood stages to children's completed schooling and risk of having a premarital birth, by sex

\begin{tabular}{|c|c|c|c|c|}
\hline & \multicolumn{2}{|c|}{$\begin{array}{l}\text { Years of completed } \\
\text { schooling }\end{array}$} & \multicolumn{2}{|c|}{ Nonmarital birth } \\
\hline & $\begin{array}{l}\text { Sons } \\
\text { coeff } \\
\text { (std.err.) }\end{array}$ & $\begin{array}{l}\text { Daughters } \\
\text { coeff. } \\
\text { (std.err.) }\end{array}$ & $\begin{array}{l}\text { Daughters } \\
\text { coeff } \\
\text { (std.err.) }\end{array}$ & Risk \\
\hline \multicolumn{5}{|l|}{ Age $0-5$} \\
\hline \multicolumn{5}{|l|}{ Family structure: } \\
\hline Mother-only & $\begin{array}{c}-0.20 \\
(0.21)\end{array}$ & $\begin{array}{c}0.32^{+} \\
(0.19)\end{array}$ & $\begin{array}{c}-0.35 \\
(0.28)\end{array}$ & 0.70 \\
\hline Mother with grandparents & $\begin{array}{r}-0.02 \\
(0.32)\end{array}$ & $\begin{array}{r}-0.02 \\
(0.33)\end{array}$ & $\begin{array}{c}-0.32 \\
(0.46)\end{array}$ & 0.73 \\
\hline Mother w/ stepfather (age $0-10$ ) & $\begin{array}{c}-0.21 \\
(0.33)\end{array}$ & $\begin{array}{r}-0.52^{+} \\
(0.29)\end{array}$ & $\begin{array}{c}-0.02 \\
(0.52)\end{array}$ & 0.98 \\
\hline Other nonintact family & $\begin{array}{c}-0.17 \\
(0.26)\end{array}$ & $\begin{array}{r}-0.45^{+} \\
(0.23)\end{array}$ & $\begin{array}{c}0.34 \\
(0.33)\end{array}$ & 1.40 \\
\hline Average family income ${ }^{a}$ & $\begin{array}{l}0.17^{* *} \\
(0.06)\end{array}$ & $\begin{array}{l}0.12^{* *} \\
(0.04)\end{array}$ & $\begin{array}{c}-0.04 \\
(0.31)\end{array}$ & 0.96 \\
\hline \multicolumn{5}{|l|}{ Age 6-10 } \\
\hline \multicolumn{5}{|l|}{ Family structure: } \\
\hline Mother-only & $\begin{array}{c}-0.17 \\
(0.26)\end{array}$ & $\begin{array}{c}0.19 \\
(0.20)\end{array}$ & $\begin{array}{c}0.36 \\
(0.30)\end{array}$ & 1.43 \\
\hline Mother with grandparents & $\begin{array}{c}-0.23 \\
(0.52)\end{array}$ & $\begin{array}{l}0.36 \\
(0.59)\end{array}$ & $\begin{array}{c}0.54 \\
(0.65)\end{array}$ & 1.72 \\
\hline Mother w/ stepfather (see above) & - & - & $\begin{array}{ll}- \\
-\end{array}$ & \\
\hline Other nonintact family & $\begin{array}{c}0.29 \\
(0.30)\end{array}$ & $\begin{array}{c}-0.06 \\
(0.25)\end{array}$ & $\begin{array}{c}0.48 \\
(0.37)\end{array}$ & 1.61 \\
\hline Average family income ${ }^{a}$ & $\begin{array}{c}-0.02 \\
(0.04)\end{array}$ & $\begin{array}{l}0.02 \\
(0.04)\end{array}$ & $\begin{array}{c}-0.01 \\
(0.12)\end{array}$ & 0.99 \\
\hline \multicolumn{5}{|l|}{ Age 11-15 } \\
\hline $\begin{array}{l}\text { Family structure: } \\
\text { Mother-only }\end{array}$ & $\begin{array}{c}0.02 \\
(0.23)\end{array}$ & $\begin{array}{r}-0.34^{+} \\
(0.19)\end{array}$ & $\begin{array}{c}0.18 \\
(0.33)\end{array}$ & 1.20 \\
\hline Mother with grandparents & $\begin{array}{c}-0.84^{*} \\
(0.40)\end{array}$ & $\begin{array}{r}-1.07^{*} \\
(0.44)\end{array}$ & $\begin{array}{c}0.84 \\
(0.55)\end{array}$ & 2.32 \\
\hline Mother w/ stepfather (age 11-15) & $\begin{array}{c}0.34 \\
(0.30)\end{array}$ & $\begin{array}{c}0.19 \\
(0.24)\end{array}$ & $\begin{array}{c}0.40 \\
(0.46)\end{array}$ & 1.49 \\
\hline Other nonintact family & $\begin{array}{c}-0.21 \\
(0.24)\end{array}$ & $\begin{array}{l}0.08 \\
(0.23)\end{array}$ & $\begin{array}{c}0.04 \\
(0.36)\end{array}$ & 1.04 \\
\hline Average family income ${ }^{a}$ & $\begin{array}{c}-0.02 \\
(0.04)\end{array}$ & $\begin{array}{c}-0.00 \\
(0.02)\end{array}$ & $\begin{array}{c}-0.25^{* *} \\
(0.08)\end{array}$ & 0.78 \\
\hline Adjusted R-squared/log likelihood & 0.211 & 0.312 & -630.5 & \\
\hline
\end{tabular}

${ }^{\text {a }}$ Family income is measured in $\$ 10,000$ dollars and inflated to the 1993 price levels using Consumer Price Index CPI-UX1.

$+, *, * *, * *$ denotes estimate is statistically significant at $0.10,0.05,0.01$ and 0.001 level respectively.

Other predictors include age at censoring, ethnicity, mother's education, age of mother at birth of child, nonmissing data on age of mother at birth, total number of siblings, ever lived in south, average county unemployment rate at age 11-15, and average state AFDC benefit at age 14 . 
Table 5. Relationship of parental marital events at different childhood stages to children's completed schooling and risk of having a premarital birth, by sex

\begin{tabular}{|c|c|c|c|c|}
\hline & \multicolumn{2}{|c|}{$\begin{array}{l}\text { Years of completed } \\
\text { schooling }\end{array}$} & \multicolumn{2}{|c|}{ Nonmarital birth } \\
\hline & $\begin{array}{l}\text { Sons } \\
\text { coeff } \\
\text { (std.err.) }\end{array}$ & $\begin{array}{l}\text { Daughters } \\
\text { coeff. } \\
\text { (std.err.) }\end{array}$ & $\begin{array}{l}\text { Daughters } \\
\text { coeff } \\
\text { (std.err.) }\end{array}$ & Risk \\
\hline $\begin{array}{l}\text { Whether born into mother-only } \\
\text { family }\end{array}$ & $\begin{array}{c}-0.73 * * * \\
(0.21)\end{array}$ & $\begin{array}{c}-0.21 \\
(0.20)\end{array}$ & $\begin{array}{c}-0.19 \\
(0.31)\end{array}$ & 0.83 \\
\hline $\begin{array}{l}\text { Whether born into other nonintact } \\
\text { family }\end{array}$ & $\begin{array}{c}-0.83^{*} \\
(0.33)\end{array}$ & $\begin{array}{c}-0.14 \\
(0.28)\end{array}$ & $\begin{array}{c}0.90^{*} \\
(0.34)\end{array}$ & 2.46 \\
\hline \multicolumn{5}{|l|}{ Age 0-5 } \\
\hline \multicolumn{5}{|l|}{ Marital events: } \\
\hline Parental divorce/separation & $\begin{array}{l}-0.20 \\
(0.23)\end{array}$ & $\begin{array}{c}-0.21 \\
(0.23)\end{array}$ & $\begin{array}{l}1.08^{* *} \\
(0.35)\end{array}$ & 2.94 \\
\hline Parental (re)marriage & $\begin{array}{c}0.53+ \\
(0.28)\end{array}$ & $\begin{array}{c}-0.13 \\
(0.26)\end{array}$ & $\begin{array}{c}-0.65 \\
(0.48)\end{array}$ & 0.52 \\
\hline $50 \%+$ Family income loss & $\begin{array}{l}0.50^{* *} \\
(0.08)\end{array}$ & $\begin{array}{c}-0.11 \\
(0.18)\end{array}$ & $\begin{array}{c}-0.32 \\
(0.26)\end{array}$ & 0.73 \\
\hline \multicolumn{5}{|l|}{ Age 6-10 } \\
\hline \multicolumn{5}{|l|}{ Marital events: } \\
\hline Parental divorce/separation & $\begin{array}{c}-0.01 \\
(0.24)\end{array}$ & $\begin{array}{c}-0.33 \\
(0.24)\end{array}$ & $\begin{array}{l}0.87^{* *} \\
(0.33)\end{array}$ & 2.39 \\
\hline Parental (re)marriage & $\begin{array}{c}0.09 \\
(0.21)\end{array}$ & $\begin{array}{c}0.43 \\
(0.29)\end{array}$ & $\begin{array}{c}-1.05^{*} \\
(0.48)\end{array}$ & 0.35 \\
\hline $50 \%+$ Family income loss & $\begin{array}{c}-0.16 \\
(0.18)\end{array}$ & $\begin{array}{c}-0.07 \\
(0.15)\end{array}$ & $\begin{array}{c}0.10 \\
(0.25)\end{array}$ & 1.11 \\
\hline \multicolumn{5}{|l|}{ Age 11-15 } \\
\hline \multicolumn{5}{|l|}{ Marital events: } \\
\hline Parental divorce/separation & $\begin{array}{c}0.50^{*} \\
(0.23)\end{array}$ & $\begin{array}{r}-0.49^{*} \\
(0.22)\end{array}$ & $\begin{array}{l}0.96^{* *} \\
(0.36)\end{array}$ & 2.61 \\
\hline Parental (re)marriage & $\begin{array}{l}-0.84^{* *} \\
(0.26)\end{array}$ & $\begin{array}{l}0.69^{* *} \\
(0.25)\end{array}$ & $\begin{array}{l}-0.47 \\
(0.39)\end{array}$ & 0.63 \\
\hline $50 \%+$ Family income loss & $\begin{array}{c}-0.37^{*} \\
(0.16)\end{array}$ & $\begin{array}{l}-0.21 \\
(0.15)\end{array}$ & $\begin{array}{c}-0.01 \\
(0.04)\end{array}$ & 0.99 \\
\hline Adjusted R-squared/log likelihood & 0.208 & 0.278 & -640.8 & \\
\hline
\end{tabular}

$+, *, * *, * *$ denotes estimate is statistically significant at $0.10,0.05,0.01$ and 0.001 level respectively.

Other predictors include age at censoring, ethnicity, mother's education, age of mother at birth of child, nonmissing data on age of mother at birth, total number of siblings, ever lived in south, average county unemployment rate at age 11-15, and average state AFDC benefit at age 14 .

mother-with-stepfather families in early to mid childhood appear to complete less education than their counterparts in intact or mother-only families at that time; however, the evidence is not strong (significant at the 0.1 level). Daughters in mother-with-stepfather families in adolescence appear to complete more education than their counterparts in mother-only families; again the evidence is not strong $(0.1$ level). Both mother-with-stepfather and mother-only structures seem to be behaving differently at the two ends of daughters' childhood; standard errors are, however, quite large, suggesting caution about this conclusion. There is no evidence of the mother-with-stepfather structure being of importance to sons' subsequent educational attainment. 
It is in late childhood that the mother-with-grandparent(s) structure shows its strongest associations with subsequent educational attainment, and here the associations are similar for sons and daughters. Young adults, sons as well as daughters, who lived in a mother-with-grandparent(s) structure during their adolescent years tended to have about one year less completed schooling than otherwise similar young adults who lived in two-parent families at that stage of childhood.

From the size of the coefficients alone, it would appear that the motherwith-grandparent(s) structure in late childhood has the strongest negative association with the outcomes we examine of any non-intact structure at any childhood stage. However, this conclusion is tempered by results of statistical tests for differences in coefficients both across the late-childhood structures and for the mother-with-grandparent(s) structure across the different childhood stages. Whether the mother-with-grandparent(s) structure is, of all the non-intact structures in late childhood, the most negative in its association with subsequent educational attainment is unclear. The coefficient on the mother-with-grandparent(s) variable is (at 0.05 significance level) more negative than that of all other non-intact structures in late childhood except, for daughters, the mother-only structure and, for sons, the 'other' set of structures. More lenient significance thresholds ( 0.15 significance level) support the difference between the mother-with-grandparent(s) structure and the motheronly structure in late childhood. Tests for differences in coefficients for the mother-with-grandparent(s) structure at different childhood stages also yield results highly sensitive to the significance threshold. The coefficient on the mother-with-grandparent(s) variable in late childhood is not perceived as larger than the coefficients on that same structure at earlier childhood stages when the significance threshold is set at the 0.05 levels. A more lenient significance level of 0.10 yields significant differences for daughters, though still not sons. On the whole, the evidence suggests the cautious observation that there is a good chance that the mother-with-grandparent(s) structure in late childhood is especially detrimental to children's education. The mother-withgrandparent(s) structure clearly merits further research as something distinct from the mother-only structure.

The evidence provides little support for social control theory's contention that additional adults in non-intact families lessen detrimental influences of the structure. Children spending time in mother-with-stepfather families or mother-with-grandparent(s) families do not tend to have higher levels of subsequent educational attainment or lower risks of a nonmarital birth than those spending time in mother-only families. The one exception is daughters in mother-with-stepfather families late in childhood.

Changes in parents' marital arrangements, especially those occurring in late childhood, show several strong associations with children's adult behaviors (see Table 5). The pattern, though, varies with the type of parental event, its timing in terms of childhood stage, and the sex of the child. One pattern that holds for both sons and daughters is a tendency for parental marital disruption and parental (re)marriage to show opposite associations with the children's young adulthood outcomes. Each of these changes, however, seems to influence sons and daughters differently.

Relative to otherwise similar counterparts, daughters who experienced parental marital disruption at any childhood stage tended to have a higher risk of a nonmarital birth (two and one-half to three times as high). Daughters 
who experienced parental marital disruption in late childhood also tended to have less subsequent completed schooling (about one half year less). Sons, on the other hand, who experienced parental marital disruption in adolescence tended to have more, rather than less, subsequent educational attainment (about one-half year more) than their otherwise similar counterparts.

Parental (re)marriage experienced in middle childhood is associated with a lower risk for daughters of a nonmarital birth (one-third as high). Parental (re)marriage experienced in adolescence is associated, for daughters, with higher (about two-thirds of a year more) educational attainment. For sons, on the other hand, parental (re)marriage at that late stage of childhood is associated with less (about four-fifth of a year less) educational attainment.

The strength of the relationship between parental (re)marriage and subsequent educational attainment differs depending on the timing of this event. Much of this difference is in terms of whether there is or is not a notable association. The difference is more striking, though, in the case of early versus late childhood parental re(marriage) experienced by sons. There is weak evidence of parental (re)marriage early in childhood being associated with more (by about one-half year), rather than less (compared with, in late childhood, one year less), subsequent educational attainment. This suggests that the timing of parental marital events is especially important for sons' educational attainment.

\section{Discussion}

With data on full childhood family experiences, we estimate models of educational attainment and nonmarital births that provide a variety of views of the role of family structure in shaping children's lives. To distinguish the ways in which family structure operates, we introduce into our models various sets of control variables. We cannot entirely rule out possibilities of endogeneity for all control variables; hence our findings are tempered with some caution.

In general, our findings are more consistent with the underlying family mechanisms posited by stress theory (stress caused by disruptions in family structure) than those posited by social control theory (tighter supervision through larger numbers of parents or substitute parents). Change rather than type of structure predominates in the strength of association with children's adult behaviors, and there is no evidence that the number of adults in the child's home, per se, reduces detrimental influences of exposure to a nonintact family. We find that parental marital change has a more pronounced association with the outcomes we examine if the events occurred in late childhood. This is consistent with stress theory also, which posits that change in family structure will have its greatest effects close to the time of the change. Because educational attainment and nonmarital births are observed in the years most immediately following late childhood, it is that stage of childhood that is closest in timing.

Yet some of the findings are also at odds with stress theory. Most especially, change is not always tied to the outcomes in a detrimental way. Parental marital change is not always associated with lower educational attainment or a higher risk of nonmarital birth; it sometimes has an association in the opposite direction, and many times has no association that is statistically different from zero at conventional levels. In addition, the young adult outcomes 
we examined appear to be unrelated to several sequences of transitions in family structure.

Our analysis also allows us to investigate the economic hardship theory, matching the measure of childhood family income to that of family structure. From Tables 4 and 5 we see that childhood family income is linked to children's educational attainment and daughters' risk of a nonmarital birth, though not at all childhood stages. Average childhood family income relates to educational attainment and risk of a nonmarital birth in the expected direction: when average childhood income is included in combination with stage-specific family structure measures (not shown), income is positively related to children's education and negatively related to daughters' risk of a nonmarital birth. ${ }^{13}$ Predictive power improves, however, when the match in timing of income and family structure is tighter. ${ }^{14}$ Our disaggregation of family income allows us to see what appears to be differential concentration of family income linkages by childhood stage. It is the income during early childhood that is most strongly linked to sons' and daughters' subsequent educational attainment. On the other hand, it is the income during late childhood that most strongly links level of income to daughters' risk of a nonmarital birth. Late childhood also appears to be the time of strongest linkage between income loss and subsequent lower levels of educational attainment, as the results in Table 5 indicate. Oddly enough, for sons family income loss in early childhood is associated with higher, rather than, lower, completed schooling. Especially since no similar findings appear for daughters, it is difficult to know what to make of this. Taken as a whole, childhood family income appears to play an important role in the outcomes examined, though the role is not entirely straightforward and shows strong evidence of notable differences by childhood stage.

Childhood family income does not appear to account for linkages between childhood family structure and the outcomes we examine. Those linkages appear to be largely independent of family income (a finding consistent with $\mathrm{Wu}$ 1996). When we estimate the models presented in Tables 4 and 5 omitting income as a control, the coefficients on the family-structure and parentalmarital event variables are hardly affected.

To assess other possible mechanisms, we also investigated three other ways in which childhood family structure might influence educational attainment and nonmarital birth: via intergenerational transmission of reliance on public support, reduced attention from the mother because of her greater work commitment, and disruptive influences of residential relocation. ${ }^{15}$ Of the three, residential relocation exhibits the strongest relationship to the outcomes we examine. Such moves, for daughters, are associated with reduced educational attainment if the move occurred in middle or late childhood (see Appendix Table 1). In analysis not shown here, residential moves were also found to account for part of the negative association between daughters' educational attainment and parental marital events or living in a mother-withstepfather family during adolescence. Mother's market work commitment as well as receipt of AFDC showed no notable relationships to the outcomes we examined.

Some of the findings simply do not fit the major existing theories and call out for further theoretical development. The mother-with-grandparent structure is not well understood; our findings suggest that it merits more attention in both empirical research and theories of family structure influences. Though 
our modest sample sizes preclude strong conclusions, our results suggest this type of structure experienced late in childhood could be strongly tied to reduced educational attainment and enhanced risks of a nonmarital birth. Because it is a type of structure rather than a change in structure, this finding does not fit with stress theory. Because it involves more adults than a motheronly structure, it does not fit with social control theory either. Because the strength of the relationship holds even with controls for family income, it does not fit with economic hardship theory.

Why would the mother-with-grandparent(s) structure during late childhood be so negatively related to young adult outcomes, and why would that same structure early in childhood have little association with children's longrun outcomes? One possibility is that conflicts in rearing practices may be especially important in adolescence. The two generations of adults - parent and grandparent - may have conflicting ideas about how to raise teenagers, and inconsistency in their supervisory activities undermines their ability to steer adolescents away from destructive behaviors. Another possibility is that the observed associations reflect something about the reason the structure was formed. In late childhood such a structure probably means one of two things - that the child's mother has recently had a marital disruption and is getting help from the child's grandparents or that the child's grandmother is in need of financial assistance or help with activities and has moved into the child's family to receive such help. Both possibilities can mean, relative to intact families, that less of the total family income is allocated to children, that children have less privacy, and that children are expected to devote more time to responsibilities at home. This points to differences in within-family resource allocation as a possible underlying mechanism, with family structure as a determinant of within-family resource allocation patterns (Chase-Lansdale et al. 1994).

Findings for some types of parental marital events at certain stages of childhood also merit further thought to suggest theories about the underlying mechanisms. Parental (re)marriage in late childhood is positively related to daughters' educational attainment, and in middle childhood this event is negatively related to their risk of a nonmarital birth. In addition, parental divorce or separation in late childhood is positively related to son's educational attainment. Stress theory predicts the opposite because parental marital change means change in organization. The findings for parental (re)marriage might fit with social control theory (because the change adds a substitute parent). However, why is the association of this event with subsequent educational attainment so different (and strongly negative) for sons? A possible explanation for the pattern of results regarding parental (re)marriage may lie in differences between fathers and stepfathers in their commitment to adolescents. Men who marry into families with children in or near adolescence may tend to be more supportive because they self-select themselves into that position and that responsibility. Their support may benefit girls more than boys because girls may tend to accept their support whereas boys may tend to resist it, in part because boys may resent the stepfather stepping into the father role at a time when they feel they are old enough to be 'man of the family.' It is possible that something of a mirror image accounts for the positive association of parental divorce or separation late in childhood with sons' subsequent educational attainment: boys may take adult roles more seriously when they feel they are the 'man of the family.' 
Overall, the results indicate that theories about effects of childhood family structure need to recognize that: (a) change in family structure is important, (b) the timing of family structure experiences over the course of childhood is relevant, (c) other adults in children's homes, besides just the parents, can be important, and (d) the influence of childhood family structure can vary by type of outcome and sex of the child. New theories should consider the allocation, as well as the level, of economic resources within children's homes and the reasons why people form different kinds of family structures. The development and testing of theories along these lines could call upon a variety of analytical approaches, including the use of sibling models and other techniques to control for unmeasured heterogeneity (see, for example, Sandefur and Wells 1997; Teachman et al. 1995; Griliches 1979) and consideration of techniques that account more fully for the detailed sequencing patterns of family structure over a given childhood life stage (see, for example, Rohwer and Trappe 1997, and Rohwer 1996). We encourage development and testing of new theories in these directions.

\section{Appendix}

Table A1. Means and regression coefficient estimates for predictors other than family structure or income

\begin{tabular}{|c|c|c|c|c|c|}
\hline & \multicolumn{2}{|c|}{ Means (std. dev.) } & \multicolumn{2}{|c|}{ Completed schooling } & \multirow{2}{*}{$\begin{array}{l}\begin{array}{l}\text { Nonmarital } \\
\text { childbearing }\end{array} \\
\text { Daughters }\end{array}$} \\
\hline & Sons & Daughter & Sons & Daughters & \\
\hline Age at censoring & $\begin{array}{l}21.95 \\
(1.52)\end{array}$ & $\begin{array}{l}21.78 \\
(1.50)\end{array}$ & $\begin{array}{l}0.25^{* * *} \\
(0.04)\end{array}$ & $\begin{array}{l}0.36 * * * \\
(0.04)\end{array}$ & - \\
\hline Ethnicity (black = 1) & $\begin{array}{c}0.14 \\
(0.36)\end{array}$ & $\begin{array}{c}0.15 \\
(0.37)\end{array}$ & $\begin{array}{l}0.67 * * * \\
(0.19)\end{array}$ & $\begin{array}{l}0.30^{+} \\
(0.18)\end{array}$ & $\begin{array}{l}0.60 * * \\
(0.27)\end{array}$ \\
\hline Mother's education & $\begin{array}{l}12.17 \\
(2.3)\end{array}$ & $\begin{array}{l}12.6 \\
(2.2)\end{array}$ & $\begin{array}{l}0.13 * * * \\
(0.03)\end{array}$ & $\begin{array}{l}0.14^{* * * *} \\
(0.02)\end{array}$ & $\begin{array}{c}-0.04 \\
(0.04)\end{array}$ \\
\hline $\begin{array}{l}\text { Age of mother at birth } \\
\text { of child }\end{array}$ & $\begin{array}{l}25.0 \\
(7.7)\end{array}$ & $\begin{array}{l}24.0 \\
(8.0)\end{array}$ & $\begin{array}{c}0.00 \\
(0.01)\end{array}$ & $\begin{array}{c}0.01 \\
(0.01)\end{array}$ & $\begin{array}{c}-0.07 * * \\
(0.02)\end{array}$ \\
\hline $\begin{array}{l}\text { Non-missing data on age } \\
\text { of mother at birth }\end{array}$ & $\begin{array}{c}0.97 \\
(0.18)\end{array}$ & $\begin{array}{c}0.95 \\
(0.22)\end{array}$ & $\begin{array}{c}0.16 \\
(0.45)\end{array}$ & $\begin{array}{c}0.44 \\
(0.39)\end{array}$ & $\begin{array}{c}0.96 \\
(0.74)\end{array}$ \\
\hline Number of siblings & $\begin{array}{c}2.3 \\
(1.9)\end{array}$ & $\begin{array}{l}2.3 \\
(1.9)\end{array}$ & $\begin{array}{c}-0.08 * \\
(0.03)\end{array}$ & $\begin{array}{l}-0.13^{* * *} \\
(0.04)\end{array}$ & $\begin{array}{l}0.30^{* * *} \\
(0.06)\end{array}$ \\
\hline Ever lived in south & $\begin{array}{c}0.39 \\
(0.50)\end{array}$ & $\begin{array}{c}0.36 \\
(0.49)\end{array}$ & $\begin{array}{r}-0.03 \\
(0.17)\end{array}$ & $\begin{array}{c}-0.20 \\
(0.16)\end{array}$ & $\begin{array}{c}-0.06^{* *} \\
(0.02)\end{array}$ \\
\hline $\begin{array}{l}\text { County unemployment } \\
\text { rate, age } 11-15\end{array}$ & $\begin{array}{l}7.5 \\
(2.3)\end{array}$ & $\begin{array}{l}7.8 \\
(2.6)\end{array}$ & $\begin{array}{c}-0.07 * * \\
(0.02)\end{array}$ & $\begin{array}{r}-0.03 \\
(0.02)\end{array}$ & $\begin{array}{c}-0.05 \\
(0.04)\end{array}$ \\
\hline $\begin{array}{l}\text { State AFDC benefit, age } \\
\quad 14 \text { (in } \$ 1,000 \text { ) }\end{array}$ & $\begin{array}{c}0.37 \\
(0.15)\end{array}$ & $\begin{array}{c}0.38 \\
(0.15)\end{array}$ & $\begin{array}{c}0.10 \\
(0.56)\end{array}$ & $\begin{array}{c}0.00 \\
(0.52)\end{array}$ & $\begin{array}{l}0.31^{* *} \\
(0.12)\end{array}$ \\
\hline Ever on AFDC & & & & & \\
\hline age $0-5$ & $\begin{array}{c}0.14 \\
(0.36)\end{array}$ & $\begin{array}{l}0.16 \\
(0.37)\end{array}$ & $\begin{array}{r}-0.33 \\
(0.25)\end{array}$ & $\begin{array}{r}-0.21 \\
(0.20)\end{array}$ & $\begin{array}{c}0.06 \\
(0.28)\end{array}$ \\
\hline age $6-10$ & $\begin{array}{c}0.16 \\
(0.37)\end{array}$ & $\begin{array}{c}0.19 \\
(0.40)\end{array}$ & $\begin{array}{c}-0.01 \\
(0.24)\end{array}$ & $\begin{array}{r}-0.34 \\
(0.21)\end{array}$ & $\begin{array}{r}-0.01 \\
(0.32)\end{array}$ \\
\hline age $11-15$ & $\begin{array}{c}0.14 \\
(0.36)\end{array}$ & $\begin{array}{c}0.16 \\
(0.37)\end{array}$ & $\begin{array}{c}-0.40^{+} \\
(0.23)\end{array}$ & $\begin{array}{c}-0.08 \\
(0.21)\end{array}$ & $\begin{array}{c}0.11 \\
(0.29)\end{array}$ \\
\hline
\end{tabular}


Table A1. (continued)

\begin{tabular}{|c|c|c|c|c|c|}
\hline & Means & d. dev.) & Comple & hooling & $\begin{array}{l}\text { Nonmarital } \\
\text { childbearing }\end{array}$ \\
\hline & Sons & Daughter & Sons & Daughters & Daughters \\
\hline Mother ever & & & & & \\
\hline $1,000+$ hours & & & & & \\
\hline age $0-5$ & $\begin{array}{c}0.41 \\
(0.50)\end{array}$ & $\begin{array}{c}0.43 \\
(0.50)\end{array}$ & $\begin{array}{c}0.01 \\
(0.13)\end{array}$ & $\begin{array}{c}-0.01 \\
(0.12)\end{array}$ & $\begin{array}{c}-0.25 \\
(0.23)\end{array}$ \\
\hline age $6-10$ & 0.50 & 0.52 & $-0.22^{+}$ & -0.04 & 0.17 \\
\hline & $(0.51)$ & $(0.51)$ & $(0.13)$ & $(0.13)$ & $(0.28)$ \\
\hline age $11-15$ & 0.68 & 0.68 & 0.20 & 0.11 & 0.19 \\
\hline & $(0.48)$ & $(0.47)$ & $(0.14)$ & $(0.14)$ & $(0.26)$ \\
\hline Ever moved & & & & & \\
\hline age $0-5$ & 0.66 & 0.67 & 0.01 & 0.05 & -0.07 \\
\hline & $(0.48)$ & $(0.48)$ & $(0.13)$ & $(0.12)$ & $(0.23)$ \\
\hline age $6-10$ & 0.52 & 0.49 & $-0.21^{+}$ & $-0.44^{* * *}$ & -0.13 \\
\hline & $(0.51)$ & $(0.51)$ & $(0.12)$ & $(0.11)$ & $(0.21)$ \\
\hline age $11-15$ & 0.38 & 0.39 & 0.18 & $-0.29 *$ & 0.06 \\
\hline & $(0.50)$ & $(0.50)$ & $(0.13)$ & $(0.12)$ & $(0.22)$ \\
\hline
\end{tabular}

$+, *, * *, * * *$ denotes estimate is statistically significant at $0.10,0.05,0.01$ and 0.001 level respectively.

Other predictors include 'whether ever in various family types in each developmental stage' and stage-specific family income.

\section{Endnotes}

${ }^{1}$ By "present" we mean either in an interviewed household or associated with an interviewed household but living in an institution. For PSID aficionados, this translates into a requirement that Sequence Numbers are always in the 1-59 range.

${ }^{2}$ Since the first two years of the study, nonresponse losses to the Panel have been small, and checks against other data indicate no appreciable sample biases. Weights adjust for the original oversampling of the poor and for differential nonresponse and losses to the Panel. However, attrition is likely to be tied to parental marital dissolution, and those who attrite may well be more adversely affected by the event than those who remain in the study. In addition, during the time span of PSID data used in this analysis the PSID systematically dropped from the study children living with a non-sample parent after a parental marital breakup. A PSID tracking rule specified that only sample adults were to be followed. This meant that after the breakup of parents, children were followed only if they remained with a sample parent. To the extent that the PSID weights properly correct for differential nonresponse, problems of bias created by this procedure should be minimal. It is still possible, though, that differential attrition accompanied family structure change and was of a sort that biases estimates of the relationship between childhood family structure and young adult outcomes. To allow for this possibility it would be useful to have weights adjusted for family structure changes or to model attrition as part of the analysis procedure.

${ }^{3}$ Two-parent structures with grandparent(s) present are included in this category. We make no distinction regarding presence or absence of grandparent(s) in the two-parent structure in our research.

${ }^{4}$ A person is classified as a "stepparent" if he/she reports in the retrospective substituteparenting history collected in 1985 that he/she raised the child for at least one year and was not the biological or adoptive parent of the child, and if we were able to confirm with annual interview information that the child co-resided with that person in a parent-child relationship. 
However, limiting identification of stepparent situations to this definition alone misses some stepparent situations. This is because fertility and marital histories were not gathered until 1985 and not all adults who had co-resided with children at some point prior to 1985 survived in the panel until 1985. In particular, if a man was living in the family of the child as a husband or permanent partner of the mother prior to 1985 but was lost to attrition before 1985, we could not establish a definitive relationship between that man and the child. In such cases, we assumed that the man was the biological or adoptive father if the mother reported being married to the man and the man was co-residing with the child at the time of the child's birth; otherwise, we assumed he was a stepfather.

5 The PSID estimates average across several calendar years and apply to single year of age for ages 1-15. To simulate estimates for a cross-section of children of all ages, we weighted the figures given in Table 1 according to the age distribution of children in 1980 (approximately the midpoint for the PSID data). The age distribution figures were those for July 1, $1980 \mathrm{ob}-$ tained from Bureau of the Census (1990), Table 1. We also assumed the PSID family structure distribution for age 15 applied to ages 16 and 17 as well.

${ }^{6}$ Rendall et al. (1997) find, in both British and U.S. panel data, that reports of men's fertility show an overall deficit of between one-third and one-half of non-marital births, with the deficit especially high for U.S. black men. Non-reporting accounts for most of the deficit in the nonmarital births.

7 The means (standard deviations) for Average Annual Total Family Income (in 1993 \$10,000) are: 4.49 (2.9) over all 15 years; 3.7 (2.1) during ages $0-5 ; 4.6$ (3.1) during ages $6-10$; and 5.2 (4.1) during ages 11-15. For the measure of whether ever in a non-intact family and for the sequence of family structure types, annual income is averaged over the entire childhood.

${ }^{8}$ The means (standard deviations) for whether there was a 50\% or more Income Loss are: 0.12 $(0.33)$ for ages $0-5 ; 0.15(0.37)$ for ages $6-10$; and $0.15(0.36)$ for ages $11-15$.

9 Regarding the association of ever in a non-intact family to risk of a non-marital birth, Wu and Martinson (1993) estimate coefficients of 0.50 for whites and 0.28 for blacks, both significant at the 0.01 level, and Bumpass and McLanahan's (1989) estimates are similar.

10 The coefficient (standard error) on the more aggregated version of mother-only structure is $-0.406(0.070)$ in Wojtkiewicz's (1993) odds of high school graduation regression for sons and daughters combined. The coefficients are 0.56 and 0.32 , both significant at the 0.01 level, in Wu and Martinsons' (1993) risk of premarital birth regressions for white and black daughters, respectively.

11 The coefficient (standard error) for mother-with-stepfather in Wojtkiewicz's (1993) odds of high school graduation regression is $-0.075(0.105)$. The coefficients in Wu and Martinson's (1993) risk of a non-marital birth regression are 0.47 for whites, significant at the 0.05 level, and 0.23 for blacks, not significant at the 0.05 level.

12 Moving from the single non-intact family indicator to our stage-specific, type-specific characterization and continuing to omit childhood family income from the predictors, adjusted Rsquareds increase from 0.175 to 0.189 in the education regression for boys and from 0.275 to 0.287 in the education regression for girls. The log likelihood in the nonmarital birth equation decreases from -646.4 to -642.6 .

13 The following are the coefficients (standard errors) on average childhood family income when it is substituted for stage-specific family income in the Table 4 regressions: $0.11(0.03)$ for sons's education; $0.08(0.02)$ for daughters' education; -0.28 (0.08) for daughters' risk of a nonmarital birth.

14 The R-squareds with income averaged over all of childhood are 0.206 for sons and 0.307 for daughters. The log likelihood is -634.6 . This compares to R-squareds of 0.211 and 0.312 , respectively, and a log likelihood of -630.5 with the stage-specific average family income measures of Table 4.

15 These additional predictor variables are specified as childhood-stage specific measures of: (a) family receipt of income from the Aid to Families With Dependent Children program (coded 1 if the child's family ever received income from AFDC during the specified childhood stage and zero otherwise); (b) whether the mother devoted substantial time to market work (coded 1 if the child's mother ever worked an average of 1000 or more annual hours during the specified childhood stage and zero otherwise); and (c) whether the child's family moved (coded 1 if the family ever changed residences during the specified childhood stage). Each of these variables is based on information obtained in annual interviews. Appendix Table 1 shows the means and standard deviations. 


\section{References}

Axinn WG, Thornton A (1992) The Influence of Parental Resources on the Timing of the Transition to Marriage. Social Science Research 21:261-285

Boggess S (1998) Family Structure, Economic Status, and Educational Attainment. Journal of Population Economics 11:205-222

Booth A, Brinkerhoff D, White L (1984) The Impact of Parental Divorce on Courtship. Journal of Marriage and the Family 46:85-94

Brooks-Gunn J (forthcoming) Policy and Research Issues in the Study of Remarriage. In: Dunn J, Booth A (ed.) Remarriage and Children. Erlbaum, Hillsdale, NJ

Bumpass LL (1984) Children and Marital Disruption: A Replication and Update. Demography 21:71-82

Bureau of the Census (January 1990) Current Population Reports, United States Population Estimates, by Age, Sex, Race, and Hispanic Origin: 1980 to 1988. Series P-25, No. 1045

Burton LM, Obeidallah DA, Allison K (1996) Ethnographic Insights on Social Context and Adolescent Development among Inner-City African-American Teens. In: Jessor R, Colby JA, Shweder RA (eds.) Ethnography and Human Development: Context and Meaning in Social Inquiry. University of Chicago Press, Chicago 556-579

Casper LM, Bryson KR (1998) Co-resident Grandparents and Their Grandchildren: Grandparent Maintained Families. U.S. Bureau of the Census, Population Division Working Paper No. 26, March

Chase-Lansdale PL, Brooks-Gunn J, Zamsky E (1994) Young African-American Multigenerational Families in Poverty: Quality of Mothering and Grandmothering. Child Development 65(2):373-393

Cherlin AJ (1988) The Changing American Family and Public Policy. Urban Institute Press, Washington, D.C.

Cherlin A (1978) Remarriage As An Incomplete Institution. American Journal of Sociology 86:636-650

Cherlin A, Furstenberg FF Jr, Chase-Lansdale PL, Kiernan KE, Robins PK, Morrison DR, Teitler JO (1991) Longitudinal Studies of Effects of Divorce on Children in Great Britain and the United States. Science 252:1386-1389

Conger RD, Conger KJ, Elder GH, Lorenz FO, Simons RL, Whitbeck LB (1992) A Family Process Model of Economic Hardship and Adjustment of Early Adolescent Boys. Child Development 63:526-541

Conger RD, Conger KJ, Elder GH, Lorenz FO, Simons RL, Whitbeck LB (1993) Family Economic Stress and Adjustment of Early Adolescent Girls. Developmental Psychology 29(2):206-219

DaVanzo J, Goldscheider F (1990) Coming Home Again: Returns to the Nest in Young Adulthood. Population Studies 44:241-255

Dodge K, Petit G, Bates J (1994) Socialization Mediators of the Relation Between Socioeconomic Status and Child Conduct Problems. Child Development 65:649-665

Dornbusch SM, Carlsmith JM, Bushwall SJ, Ritter PL, Leiderman H, Hastorf AH, Gross RT (1985) Single Parents, Extended Households and the Control of Adolescents. Child Development 56:326-341

Duncan GJ, Rodgers W (1990) Lone-Parent Families and Their Economic Problems: Persistent or Transitory? In: Duskin B (ed.) Lone Parents: The Economic Challenge. OECD, Paris. 43-68

Duncan GJ, Yeung W-JJ, Rodgers W (1994) Lone-parent Families in the United States: Dynamics, Economic Status and Developmental Consequences. Population 49(6):1419-1436, Paris

Ermisch J, Francesconi M (2000) Educational Choice, Families, and Young People's Earnings. Journal of Human Resources 35 (forthcoming)

Ermisch J, Francesconi M (2001) Family Structure and Children's Achievements Journal of Population Economics (forthcoming)

Elder GH Jr (1974) Children of the Great Depression: Social Change in Life Experience. University of Chicago Press, Chicago

Fitzgerald J, Gottschalk P, Moffitt R (1998) The Impact of Attrition in the PSID on Intergenerational Analysis. Journal of Human Resources 33:300-344

Goldscheider FK, Goldscheider C (1987) Moving Out and Marriage: What do Young Adults Expect? American Sociological Review 52:278-285 
Goldscheider FK, DaVanzo J (1989) Pathways to Independent Living in Early Adulthood: Marriage, Semiautonomy, and Premarital Residential Independence. Demography 26:597-614

Griliches Z (1979) Sibling Models and Data in Economics: Beginnings of a Survey. Journal of Political Economy 87(5) Part 2:S37-S64

Haveman R, Wolfe B (1994) Succeeding Generations. Russell Sage, New York

Hernandez DJ (1993) American's Children: Resources from Family, Government, and the Economy. Russell Sage Foundation, New York

Hernandez DJ (1993) America's Children: Resources From Family, Government and the Economy. Russell Sage Foundation, New York

Hetherington EM (1979) Divorce, a Child's Perspective. American Psychologist 34:851-858

Hetherington EM (1987) Family Relations Six Years After Divorce. In: Pasley K, IhingerTallman M (eds.) Remarriage and Stepparenting Today: Current Research and Theory. Guilford Press, New York

Hill MS, Duncan GJ (1987) Parental family income and the socioeconomic attainment of children. Social Science Research 16:9-73

Hofferth SL (1985) Updating Children's Life Course. Journal of Marriage and the Family 47:93115

Hogan DP, Kitagawa EM (1985) The Impact of Social Status, Family Structure, and Neighborhood on the Fertility of Black Adolescents. American Journal of Sociology 90:825855

Kirby JB, Uhlenberg P (1999) The Wellbeing of Adolescents: Do Coresident Grandparents Make a Difference? Working paper, University of North Carolina

Krein SF (1986) Growing Up in a Single Parent Family: The Effect on Education and Earnings of Young Men. Family Relations 35:161-168

Krein SF, Beller AH (1988) Educational Attainment of Children from Single-Parent Families: Differences by Exposure, Gender, and Race. Demography 25:221-234

McLanahan S (1988) Family Structure and Dependency: Early Transitions to Female Household Headship. Demography 25(1):1-16

McLanahan S, Sandefur G (1994) Growing up With a Single Parent. Harvard University Press, Cambridge, MA

McLanahan S, Bumpass L (1988) Intergenerational Consequences of Family Disruption. American Journal of Sociology 94(1):130-152

McLeod JD, Shanahan MJ (1993) Poverty, Parenting and Children's Mental Health. American Sociological Review 58:351-366

McLoyd V, Jayaratne T, Ceballs R, Borquez J (1994) Unemployment and Work Interruption among African American Single Mothers: Effects on Parenting and Adolescent Socioemotional Functioning. Child Development 65:562-589

Moffitt R, Rendal M (1993) Cohort Trends in the Lifetime Distribution of Female Headship in the U.S., 1968-1985. Population Studies and Training Center, Brown University. Mimeo

Moorman JE, Hernandez DJ (1989) Married-Couple Families with Step, Adopted, and Biological Children. Demography 26(2):267-277

Mauldon J, Maestas N (1998) Which Children Live with Their Grandparents, and Why? Working paper, Berkeley, Goldman School of Public Policy

Mueller C, Pope H (1977) Marital Instability: A Study of the Transmission between Generations. Journal of Marriage and the Family 39:83-92

Pattillo-McCoy M (1999) Black Picket Fences: Privilege and Peril Among the Black Middle Class. University of Chicago Press, Chicago

Rendall M, Clarke L, Peters E, Ranjit N, Verropoulou G (1999) Incomplete Reporting of Men's Fertility in the United States and Britain: A Research Note. Demography 36(1):135-144

Rohwer G (1996) TDA User's Manual, Part IX: Sequence Data. Max Planck Institut fur Bildungsforschung, Berlin

Rohwer G, Heike T (1997) Describing Life Courses. An Illustration Based on NLSY Data. Paper prepared for the POLIS project conference at the European University Institute, Florence, February 28-March 1, 1997

Rubin LB (1976) Worlds of Pain: Life in the Working-Class Family. Basic, New York

Sandefur G, Wells T (1997) Using Siblings to Investigate the Effects of Family Structure on Educational Attainment. Institute for Research on Poverty. Discussion Paper No. 1144-97

Sandefur G, McLanahan S, Wojtkiewicz R (1992) The Effects of Parental Marital Status during Adolescence on High School Graduation. Social Forces 71:103-121 
Seltzer JA (1994) Consequences of Marital Dissolution for Children. Annual Review of Sociology 20:235-266

Steinberg L (1987) Single Parents, Stepparents, and the Susceptibility of Adolescents to Antisocial Peer Pressure. Child Development 58:269-275

Teachman JD, Carver K, Day R (1995) A Model for the Analysis of Paired Data. Journal of Marriage and the Family 57:1011-1024

Thornton A (1991) Influence of the Marital History of Parents on the Marital and Cohabitational Experiences of Children. American Journal of Sociology 96(4):868-894

Thornton A, Camburn D (1987) The Influence of the Family on Premarital Sexual Attitudes and Behavior. Demography 24:323-340

Weiss R (1979) Growing Up A Little Faster: The Experience of Growing Up in a Single-Parent Household. Journal of Social Issues 35:97-111

Wojtkiewicz RA (1993) Simplicity and Complexity in the Effects of Parental Structure on High School Graduation. Demography 30(4):701-717

Wu LL (1996) Effects of Family Instability, Income, and Income Instability on the Risk of A Premarital Birth. American Sociological Review 61:386-406

Wu LL, Martinson BC (1993) Family Structure and The Risk of A Premarital Birth. American Sociological Review 58:210-232

Zill N, Nord CW (1994) Running In Place: How American Families Are Faring in A Changing Economy and An Individualistic Society. Child Trends, Inc. 